\title{
Review
}

\section{Intratumoral Heterogeneity in Differentiated Thyroid Tumors: An Intriguing Reappraisal in the Era of Personalized Medicine}

\author{
Antonio Ieni ${ }^{1, *(\mathbb{D}}$, Roberto Vita ${ }^{2}$, Cristina Pizzimenti ${ }^{3}$, Salvatore Benvenga ${ }^{2,4,5}$ and Giovanni Tuccari ${ }^{1}{ }^{1}$ \\ 1 Department of Human Pathology in Adult and Developmental Age "Gaetano Barresi", Section of Pathology, \\ University of Messina, 98125 Messina, Italy; tuccari@unime.it \\ 2 Department of Clinical and Experimental Medicine, University of Messina, Viale Gazzi, 98125 Messina, Italy; \\ roberto.vita@unime.it (R.V.); sbenvenga@unime.it (S.B.) \\ 3 Department of Biomedical, Dental, Morphological and Functional Imaging Sciences, University of Messina, \\ Viale Gazzi, 98125 Messina, Italy; cristina.pizzimenti@unime.it \\ 4 Master Program on Childhood, Adolescent and Women's Endocrine Health, University of Messina, \\ Viale Gazzi, 98125 Messina, Italy \\ 5 Interdepartmental Program of Molecular \& Clinical Endocrinology and Women's Endocrine Health, \\ University Hospital, A.O.U. Policlinico G. Martino, Viale Gazzi, 98125 Messina, Italy \\ * Correspondence: aieni@unime.it; Tel.: +39-90-221-2536; Fax: +39-90-292-8150
}

check for

updates

Citation: Ieni, A.; Vita, R.;

Pizzimenti, C.; Benvenga, S.; Tuccari,

G. Intratumoral Heterogeneity in

Differentiated Thyroid Tumors: An Intriguing Reappraisal in the Era of Personalized Medicine. J. Pers. Med. 2021, 11, 333. https://doi.org/ 10.3390/jpm11050333

Academic Editors: Cristina L. Ronchi and Barbara Altieri

Received: 30 March 2021

Accepted: 21 April 2021

Published: 23 April 2021

Publisher's Note: MDPI stays neutral with regard to jurisdictional claims in published maps and institutional affiliations.

Copyright: (c) 2021 by the authors. Licensee MDPI, Basel, Switzerland. This article is an open access article distributed under the terms and conditions of the Creative Commons Attribution (CC BY) license (https:// creativecommons.org/licenses/by/ $4.0 /)$.

\begin{abstract}
Differentiated thyroid tumors (DTTs) are characterized by significant molecular variability in both spatial and temporal intra-tumoral heterogeneity (ITH), that could influence the therapeutic management. ITH phenomenon appears to have a relevant role in tumor growth, aggressive behavior and drug resistance. Accordingly, characteristics and consequences of ITH in DTTs should be better analyzed and understood in order to guide clinical practice, improving survival. Consequently, in the present review, we investigated morphological and molecular ITH of DTTs in benign, borderline neoplasms and in malignant entities, summarizing the most significant data. Molecular testing in DTTs documents a high risk for recurrence of cancer associated with BRAFV600E, RET/PTC 1/3, ALK and NTRK fusions, while the intermediate risk may be related to BRAFK601E,$H / K / N$ RAS and PAX8/PPAR $\gamma$. In addition, it may be suggested that tumor genotype is associated with peculiar phenotype.
\end{abstract}

Keywords: intratumoral heterogeneity; thyroid tumor; BRAF; RET/PTC rearrangements; RAS mutation

\section{Introduction}

Intratumoral heterogeneity (ITH) represents a crucial determinant to explain the appearance of therapeutic resistance and treatment failure, resulting in poor prognosis and outcome. This intralesion mechanism is defined as diversity observed within a tumor since mosaics of different neoplastic clones are present in the same tumor at varying time [1]. ITH can exist either between geographical areas of the same tumor (spatial heterogeneity) or between different lesions that appear over time locally or distantly (temporal heterogeneity) (Figure 1) [1,2].

Temporal ITH leads to discordance between the primary tumor and the metastatic lesion, and it can stem from either two mutations in different clones in the primary tumor, one clone disseminating to the metastatic site or from a new mutation occurring in the metastatic lesion [3]. ITH may determine the development of different cell subpopulations which in turns may influence the response of a tumor to changes within the microenvironment $[3,4]$. In addition, this phenomenon may create a neoplastic diffusion throughout the body, realizing metastatic deposits or acquiring resistance to therapeutic agents. Therefore, ITH analysis can provide relevant information to define innovative and patient-tailored therapeutic strategies, based on detection of specific molecular alterations [2,4-6]. So far, ITH has been addressed at both morphological and molecular levels with different 
methods [7-10]. Specifically, microdissection is essential to define morphological heterogeneity, which includes histotype, tissue composition, inflammatory reaction, center and borders of tumors [6,8]. Indeed, at a microscopic level, pathologists can recognize different histological patterns in each tumor, with specific morphological characteristics, such as necrosis, apoptosis, fibrosis, hemorrhagic areas, stromal reaction and neo-angiogenesis. An operative workflow to analyze ITH in tumors should be based on morphology, requiring an examination of extensive neoplastic areas to identify the different histological portions of the tumor, analyzing at least two or more representative different portions obtained by microdissection procedure (Figure 2). However, the intratumoral differentiation (well-, moderately-, poorly-) is frequently focal, leading to morphofunctional differences. Furtherly, the choice of tissue specimens may depend on the location of the tumor infiltration front, with elements able to invade capsule and stroma, in contrast to central neoplastic section (Figure 2). Then, the dissected portions have to be passed in a tube for the RNA/DNA sequencing as well as proteomic profiling (Figure 2).

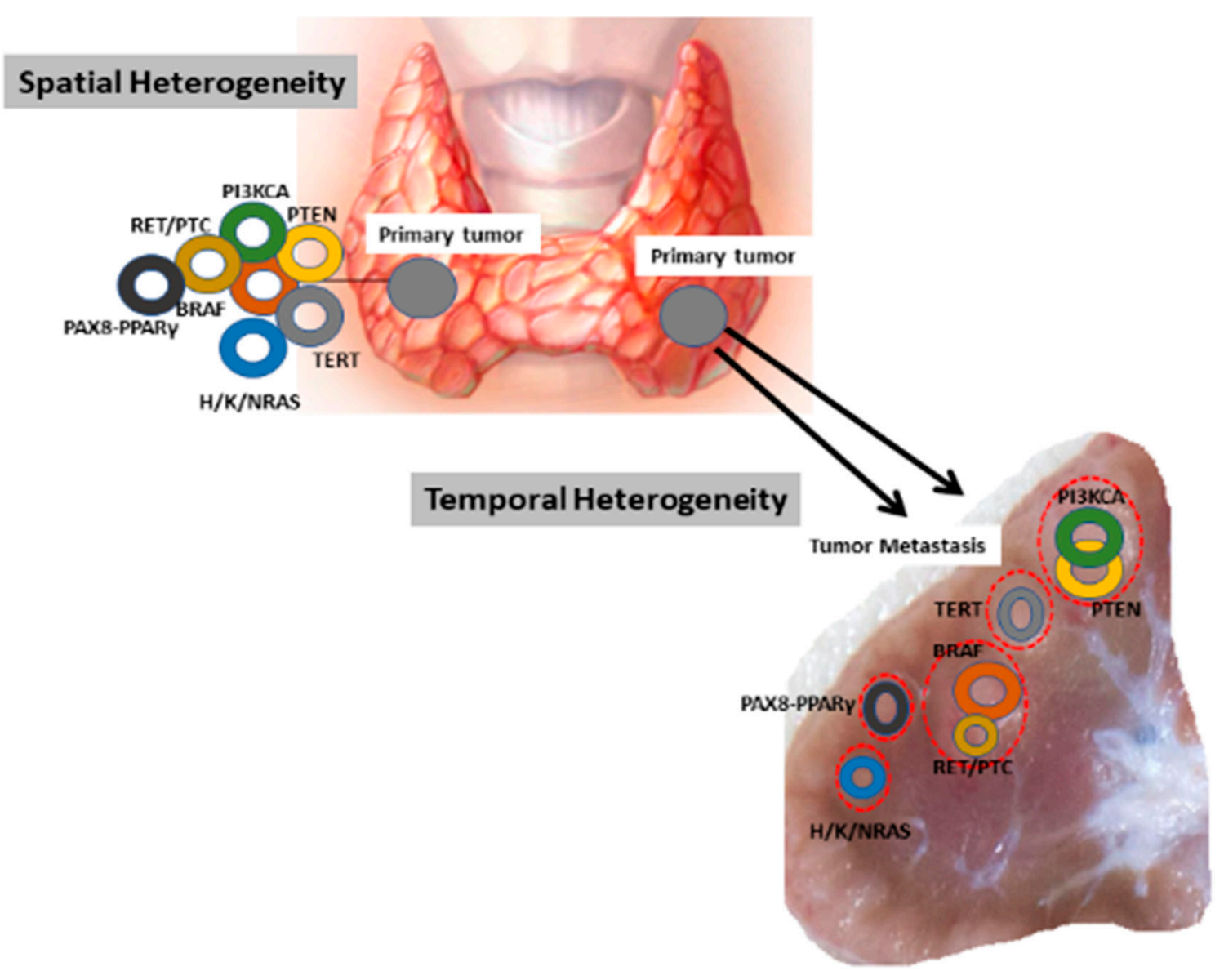

Figure 1. Spatio-temporal heterogeneity in primary and corresponding lymph node metastasis in thyroid tumors.

In addition to the inter-tumor heterogeneity, namely diversity between individuals having the same tumor type, ITH may result in different histological and cytological patterns in the same tumor, negatively impacting on the patient's prognosis [11-13]. At the molecular level, genetic and epigenetic heterogeneity can be present [14]. Particularly, immunohistochemistry, in situ hybridization methods and next generation sequencing by detecting mutations of the driver genes secondary to genetic instability may help reveal clonal and/or non-clonal heterogeneity, which are associated to phenotypic alterations driving neoplastic progression and resistance to targeted therapy [6,15-19]. 


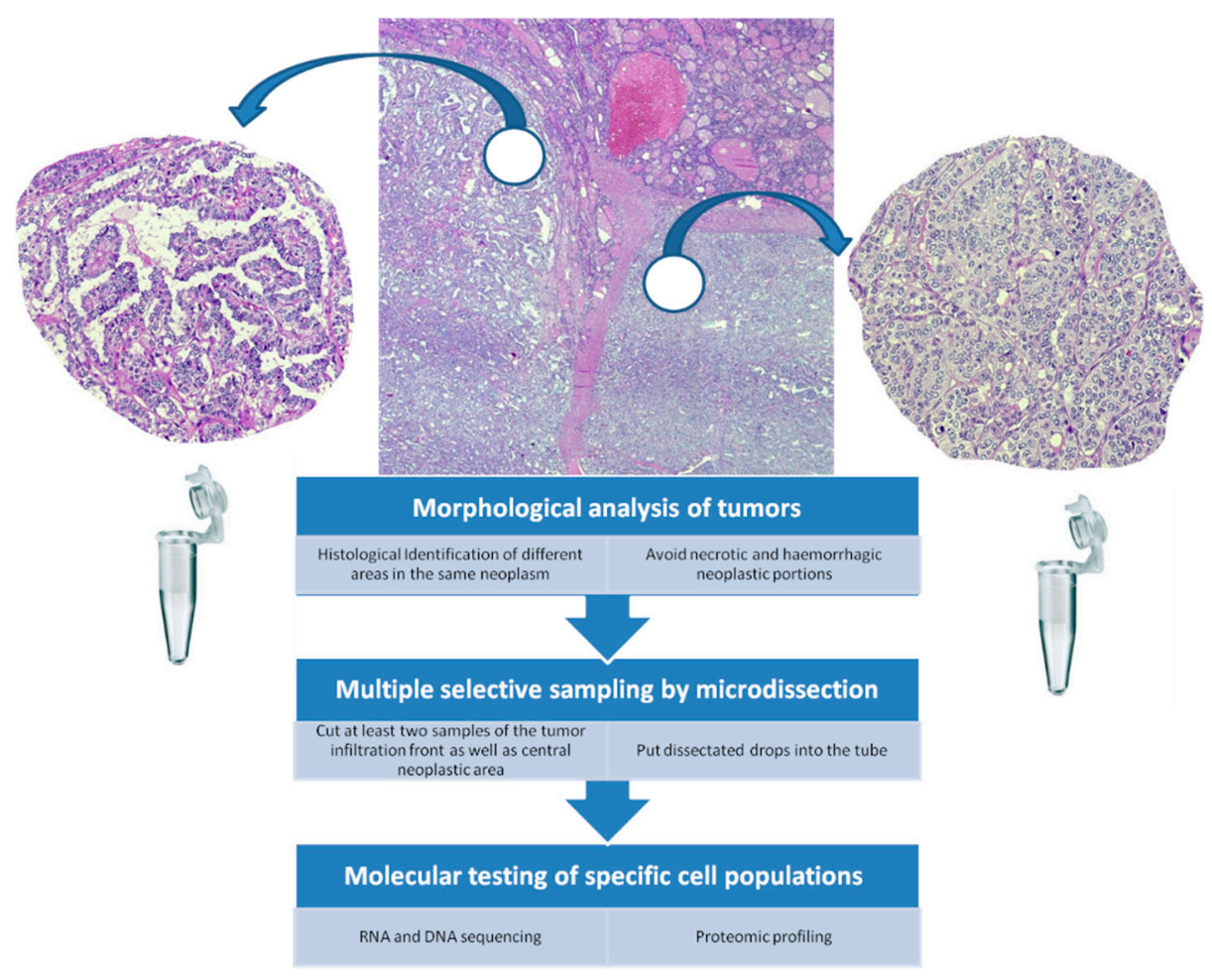

Figure 2. A schematic proposed workflow to identify ITC and to perform molecular tests in DTC.

One of the most evident examples of ITH is encountered in thyroid carcinomas and adenomas. Although the majority of differentiated thyroid carcinomas (DTCs) show an indolent behavior with an excellent prognosis, as documented by a 10-years survival rate of $90 \%$, approximately $10 \%$ of them are aggressive, tend to recur and lead the patient to death [20-24]. In this regard, a broad ITH is evident, with histotypes spanning from thyroid papillary microcarcinoma through anaplastic carcinoma, the latter representing the late and fatal stage of carcinogenesis [25-29].

The present paper should be considered as a review in order to furnish the "state of art" regarding ITH in differentiated thyroid tumors (DTCs). The major endpoint is to comparatively analyze morphological and molecular ITH of differentiated thyroid tumors (DTTs), either follicular adenoma (FA) either DTCs in order to evaluate their behavior, identifying markers for therapeutic approaches and making individualized their management. Regarding the novelty of the present review, probably there are not additional original data, but a relevant number for information concerning molecular variability in DTCs in relation to the corresponding morphological aspects as well as a precise definition of the operative workflow to reveal ITH.

\section{Phenotypic and Molecular Heterogeneity in FA and Follicular-Patterned Borderline Lesions}

To define morphological ITH in DTTs, we need to introduce the new classification of thyroid tumors, in which some changes were introduced [30-34]. In fact, together with follicular adenoma (FA), some borderline entities were added, such as tumors with uncertain malignant potential (UMP), noninvasive follicular thyroid neoplasms with papillary-like nuclear features (NIFTP) and hyalinizing trabecular tumor (HTT) [30,32] (Figure 3). FA were defined as benign, encapsulated and non-invasive neoplasm demonstrating evidence of thyroid follicular cell differentiation without nuclear features observed in papillary thyroid carcinoma (PTC) [30]. According to the 2017 WHO classification [35], the group of encapsulated follicular-patterned UMP tumors is divided into two entities: follicular tumors with uncertain malignant potential (FT-UMP) and well-differentiated tumors with 
uncertain malignant potential (WDT-UMP) (Figure 3A). FT-UMP is an encapsulated and/or well-circumscribed tumor with round nuclei that lack PTC-like features, whereas WDTUMP presents a similar gross morphology but, well/partially developed nuclear changes of PTC and questionable capsular or vascular invasion [36,37].

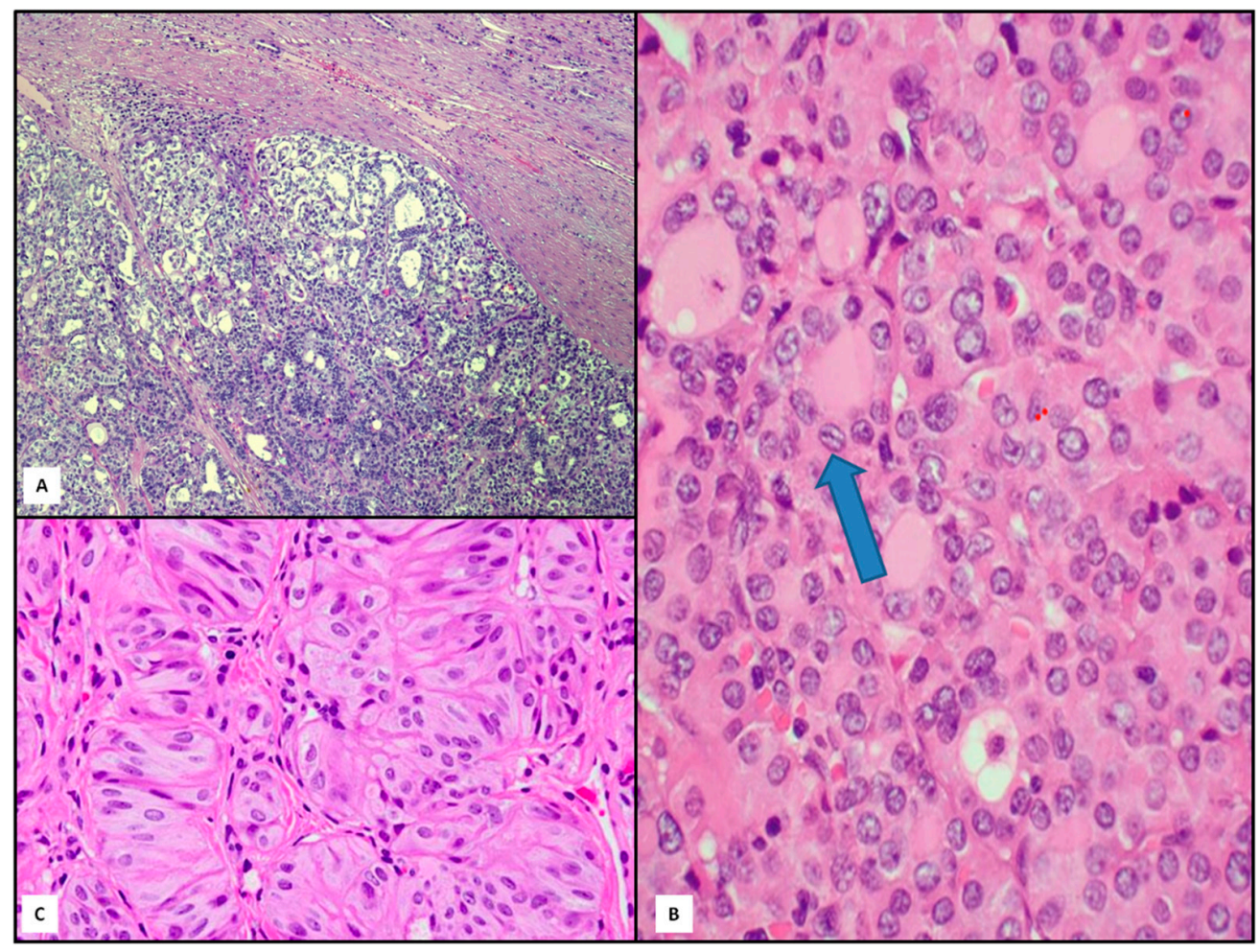

Figure 3. Histological findings of follicular-patterned borderline lesions: tumor with uncertain malignant potential (UMP) ((A), hematoxylin and eosin, $80 \times)$, noninvasive follicular thyroid neoplasms with papillary-like nuclear features (NIFTP) ((B), hematoxylin and eosin, $400 \times$ ) and hyalinizing trabecular tumor $(\mathrm{HTT})((\mathrm{C})$, hematoxylin and eosin, 200×). The arrow underlines the peculiar irregular nuclear membranes.

NIFTP is a solitary encapsulated nodule displaying the following features: a complete, frequently thick, fibrous capsule delimitating the tumor from adjacent tissue, follicular growth pattern and nuclear features of PTC [38] (Figure 3B). Papillae and capsular or vascular invasion are constantly absent [38,39]. Furthermore, NIFTP may be distinguished from both FA and hyperplastic nodule by the presence of the typical nuclear changes of PTC [40-43] (Figure 3B).

Another new interesting follicular-derived borderline lesion is represented by HTT, a well circumscribed solid neoplasm without capsular/vascular invasion or invasion of thyroid tissue adjacent to the tumor. Histologically, HTT is composed of trabeculae or sometimes nests of polygonal eosinophilic large cells intermingled with thin stromal bundles. This lesion maybe associated with chronic thyroiditis, nodular goiter or PTC [44-46] (Figure 3C).

Molecular profiles concerning classical FA and follicular-patterned borderline tumors are quite different (Table 1). 
Table 1. Histological and molecular heterogeneity in FA and follicular-patterned borderline lesions ( $\mathrm{H}, \mathrm{K}, \mathrm{N}$ isoforms of RAS gene family).

\begin{tabular}{|c|c|c|c|c|c|c|c|}
\hline & \multicolumn{7}{|c|}{ Mutations } \\
\hline & PAX8-PPAR $\gamma$ & EIF1AX & EZH1 & GNAS & RAS & BRAF & RET/PTC \\
\hline FA & $5-20 \%$ & $5-10 \%$ & $3 \%$ & $\sim 80 \%$ & HRAS $8 \%$, KRAS $10 \%$, NRAS $6 \%$ & - & - \\
\hline NIFTP & $5 \%$ & - & - & - & $\mathrm{H} / \mathrm{N} / \mathrm{KRAS}(45 \%)$ & - & - \\
\hline HTT & - & - & - & - & NRAS $0 \%$ & - & $47 \%$ \\
\hline FT/WDT-UMP & $<5 \%$ & - & - & - & $\begin{array}{c}\text { HRAS 3-12\%, KRAS 6-9\%, } \\
\text { NRAS } 16-35 \%\end{array}$ & - & - \\
\hline
\end{tabular}

For instance, paired box gene 8 (PAX8)-peroxisome proliferator-activated receptor- $\gamma$ $(\operatorname{PPAR} \gamma)$ rearrangements are detected in about $5-20 \%$ of FA, but they are absent in nonpathological thyroid parenchyma surrounding FA or in the hyperplastic nodules [47-49]. Of the other somatic genetic alterations, Eukaryotic Translation Initiation Factor 1A X-Linked (EIF1AX) gene activating mutation is found in $5-10 \%$ of FA [50,51], while telomerase reverse transcriptase (TERT) promoter mutation are very rare in genuine FA and occasionally present in FA with atypical features [50,52]. Additionally, mutations concerning Enhancer of zeste 1 polycomb repressive complex 2 subunit (EZH1) gene are detected in $3 \%$ of the FA, frequently in association with the TSH-receptor (TSHR) and/or the guanine nucleotide binding protein, alpha stimulating (GNAS) mutations, and accounting for nearly $80 \%$ of cases in some series $[33,47,53]$. RAS mutations exhibit different rates in FA: mutations in HRAS are detected in $8 \%$, in NRAS in $6 \%$ and in KRAS in $10 \%$, respectively $[51,54,55]$. Interestingly, RAS mutations have a higher prevalence in FA of persons living in area of iodine deficiency [56]. In UMP tumors, HRAS mutation are present in $3-12 \%$ of cases at codon 61 , similarly to KRAS mutations (6-9\% of cases), but less frequently than NRAS mutations (16-35\% of cases) $[50,51,54,55]$. However, H/N/K-RAS mutations are detected in $45 \%$ of NIFTP cases, while $\mathrm{BRAF}^{\mathrm{V} 600 \mathrm{E}}$ mutation and Rearranged during transfection (RET) fusions are absent [51,55]. Finally, HTT lacks BRAF or NRAS mutations, but it has considerable frequency of RET/PTC rearrangements (47\%) similar to that encountered in PTC $[55,57]$.

\section{Phenotypic and Molecular Heterogeneity in FTC}

Follicular thyroid carcinomas (FTCs), which are well-known more aggressive cancer compared with PTCs, have a prevalent histologic presentation as microfollicular or trabecular patterns, and a less frequent architecture with follicular and colloid-rich morphology [58,59]. There are also morphological rarer subtypes that are predictive of a worse prognosis, including spindle cells, clear cells, signet-ring cells, rhabdoid and insular phenotypes $[60,61]$. Generally, regardless of histotype, FTCs present a thin or thick fibrous capsule that contains some small vessels; consequently, capsular invasion produces an incomplete delimitation of the tumor and becomes an indicator of vascular invasion. Based on the extent of capsular/vascular invasion, FTCs may be divided into two subgroups of prognostic significance, minimally invasive FTCs (Figure 4A) and widely invasive FTCs [60,61]. In 2015 the prognostic subgroups became four: minimally invasive with capsular invasion, minimally invasive with limited [ $<4$ vessels) vascular invasion, minimally invasive with extensive $[\geq 4$ vessels) vascular invasion and widely invasive [59,62]. Recently, the last 2017 WHO classification suggested a 3-tiered risk groups: minimally invasive [capsular invasion only), encapsulated angio-invasive and widely invasive [59-63]. 


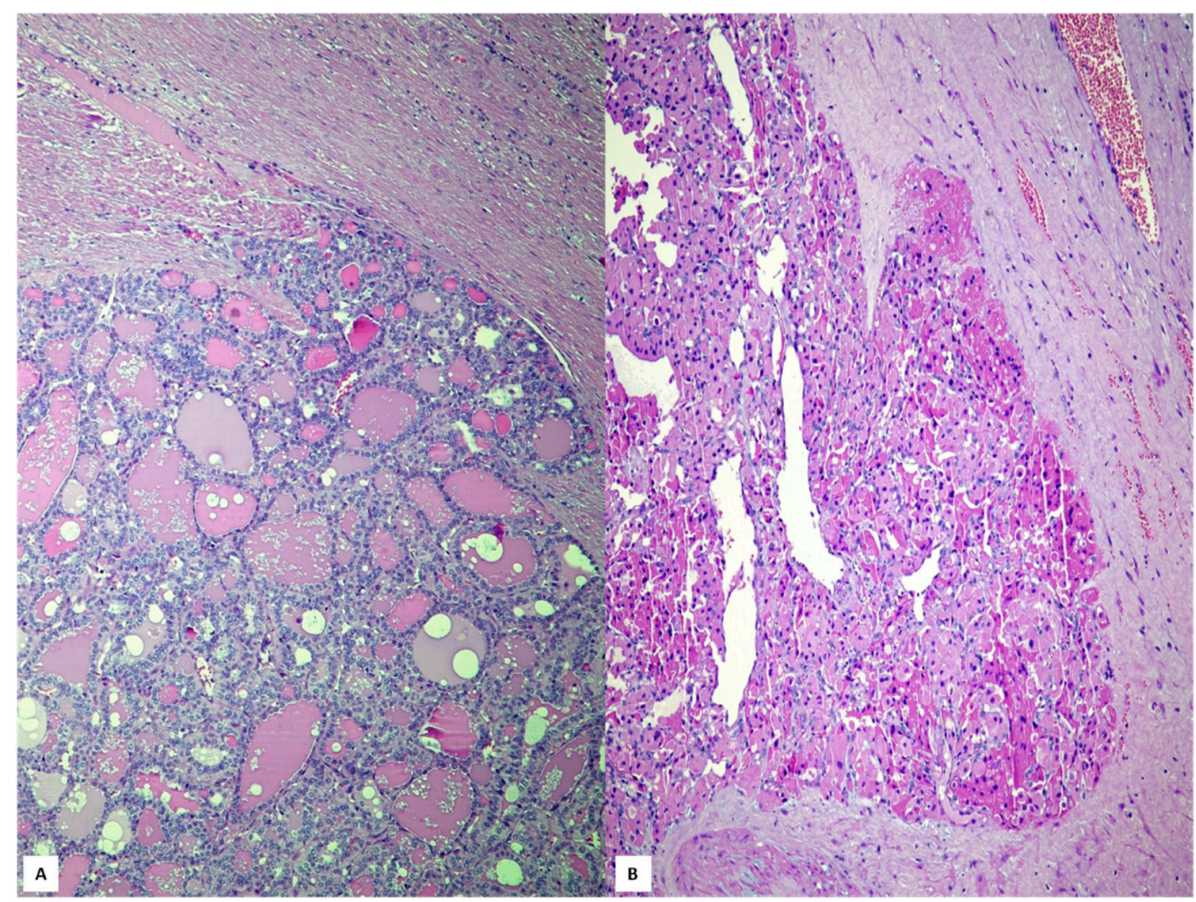

Figure 4. The follicular thyroid carcinoma with minimally invasive capsular infiltration ((A), hematoxylin and eosin, $80 \times)$; malignant Hürthle cell tumor characterized by an evident capsular invasion ((B), hematoxylin and eosin, $100 \times)$.

From a molecular perspective, the major driving mutations of FTCs are those in the RAS family of genes; for this reason, these tumors are also known as RAS-like tumors $[30,51,64,65]$ (Table 2).

Table 2. Histological and molecular heterogeneity in FTC and HCT.

\begin{tabular}{|c|c|c|c|c|c|c|c|c|c|}
\hline & \multicolumn{9}{|c|}{ Mutations } \\
\hline & PIK3CA & EIF1AX & TP53 & $\begin{array}{l}\text { PAX8- } \\
\text { PPAR } \gamma\end{array}$ & RAS & BRAF & TERTp & NF1 & MADCAM-1 \\
\hline FTC & $10 \%$ & $6 \%$ & $3 \%$ & $10-50 \%$ & $\begin{array}{l}\text { HRAS } 8 \% \\
\text { KRAS 6\%, } \\
\text { NRAS } 19 \%\end{array}$ & $1 \%$ & $\begin{array}{l}17- \\
25 \%\end{array}$ & - & - \\
\hline $\begin{array}{c}\text { Poorly } \\
\text { differentiated } \\
\text { FTC }\end{array}$ & $0-15 \%$ & - & $10-30 \%$ & $<3 \%$ & $\begin{array}{c}\mathrm{H} / \mathrm{N} / \mathrm{KRAS} \\
(10-40 \%)\end{array}$ & $5-30 \%$ & - & - & - \\
\hline HCT & - & $11 \%$ & $7 \%$ & $<5 \%$ & $\begin{array}{c}\text { KRAS } \\
11 \% \text { NRAS } 6 \%\end{array}$ & - & $17 \%$ & $7 \%$ & $20 \%$ \\
\hline
\end{tabular}

In detail, the three concurrent somatic $\mathrm{H} / \mathrm{N} / \mathrm{K}-\mathrm{RAS}$ mutation were detected with different percentage, $8 \%, 19 \%$ and $6 \%$ respectively [51]. In addition, TERT promoter (TERTp) mutations have been revealed in $25 \%$ of FTCs, which are characterized by older age of patients, larger tumor size, advanced stage (III-IV), distant metastases and disease specific mortality [52]. Several other genes, which are generally involved in Phosphoinositide 3-kinases (PI3K)/Phosphatase and tensin homolog (PTEN)/AKT pathway have been found as mutated in FTCs [66,67]. PIK3CA copy gains are encountered in FTCs $(10 \%)$ in comparison to BRAF mutations $(1 \%)[67,68]$. PTEN and PIK3CA mutations as well as PIK3CA copy gains rarely coexist in FTCs, while PI3K-PTEN-AKT pathway is common in poorly differentiated and anaplastic thyroid carcinomas, suggesting their important role in tumor progression [68,69]. Moreover, in FTCs EIF1AX mutation was identified in 
$6 \%$ of cases related with advanced disease $[67,68]$. ITH was also detected in FTCs with a range of histologic aspects, namely with follicular areas coexisting with poorly differentiated ones [67]. Interestingly, in poorly differentiated aggressive FTCs are characterized by frequent mutations in p53 (10-30\%), RAS (10-40\%), BRAF $(5-30 \%)[69,70]$, but rare PAX8/PPAR $\gamma$ rearrangements $(7-10 \%)$ have been reported [71,72]. Nevertheless, in FTCs PAX8/PPAR $\gamma$ rearrangements were revealed in female and younger patients with high cellularity and invasive aspects; this positively rearranged FTC documented a lower risk for distant metastasis [50].

Even if classified as follicular-patterned tumors, Hürthle cell tumors (HCTs) present peculiar microscopic characteristics consisting in large elements with abundant eosinophilic granular cytoplasm, centrally located nuclei and prominent nucleoli [73]. The new WHO classification distinguishes benign and malignant HCTs on the basis of capsular and vascular invasion (Figure 4B), similarly to FTCs [73]. Although believed to have a poorer prognosis compared to FTCs, it was demonstrated that Hürthle cell cancer has not higher rates of recurrence and does not concentrate less radioiodine [74-76]. Nevertheless, it has been reported that somatic genomic alterations in malignant HCTs are represented by Mucosal Vascular Address in Cell Adhesion Molecule 1 (MADCAM-1) (20\%), EIF1AX (11\%), DAXX, PT53 (7\%) and Neurofibromatosis type 1 (NF1) (7\%) mutations, while no BRAF mutations and a lower rate of NRAS (9\%) mutation are encountered in comparison to FTC cases [77-79] (Table 2). In addition, TERTp and KRAS mutations have been identified in $17 \%$ and $11 \%$ respectively; NRAS occurred with a lower percentage $(6 \%)$ [51].

\section{Phenotypic and Molecular Heterogeneity in PTC and Its Variants}

As well known, PTCs are not only the most common DTCs, but also the most common malignant entity, in that they account for over $70 \%$ of all thyroid neoplasms [80]. The classical variant presents typical microscopic features (Figure 5A), such as overlapping and clearing nuclei, irregularities of nuclear membrane in papillary architecture with fibrovascolar cores, psammoma bodies and sometimes aggregates of lymphocytes. Sixteen PTC variants with different behavior have been reported so far [81-86]. After the classic variant, the most common variants are the follicular one (Figure 5B), hobnail/micropapillary (Figure 5C), Whartin-like (Figure 5D) and solid one [81-83]. In spite of this morphological variability, molecular ITH is not constantly present, even in multifocal PTCs [84-86].

Genetic ITH of PTCs was scarcely addressed so far, partly due to the relatively low number of oncogenes involved in the early stages [87-89] (Table 3). BRAF mutations have been reported in $55 \%$ of the classical phenotype with a further significant increase in more aggressive and poorly differentiated PTCs [90,91], and in up to one third of cases of the columnar-cell variant [92,93]. In addition, BRAF mutations are frequently combined with TP53, TERTp, PIK3CA, catenin $\beta-1$ (CTNNB1), epidermal growth factor receptor (EGFR), v-akt murine thymoma viral oncogene homolog 1 (AKT1) and Notch homolog-1 (NOTCH1) mutations [83,94-96]. In the hobnail variant, the mutations detected concern BRAF (25\%), TP53 (55\%) and NOTCH1 (5\%) [83,94-96]. It is well known that mutations in BRAF and RET genes (see below) may occur both in the initial steps of carcinogenesis and in the advanced ones [97,98]. However, different foci of the same PTC may differ for their BRAF status, and such difference may also exist between a primary PTC and any of its lymph node and/or distant metastases in up to one third of cases [97-99]. For instance, BRAF ${ }^{\mathrm{V} 600 \mathrm{E}}$ mutation may occur either de novo in metastasized lymph nodes, or in metastasizing mutated cells could spread from non-analyzed PTC foci of the primary tumor [100-102]. ITH in $\mathrm{BRAF}^{\mathrm{V} 600 \mathrm{E}}$ have been also demonstrated, since only less than $50 \%$ of neoplastic elements manifested BRAF mutation $[103,104]$. Although, the prognostic role of $\mathrm{BRAF}^{\mathrm{V} 600 \mathrm{E}}$ mutation is still debatable, some studies showed an association with poor outcome, extra thyroid neoplastic extension and increased recurrence risk in PTCs [50,96-98]. By contrast, PTC with low risk clinicopathological features did not exhibit BRAF ${ }^{\mathrm{V} 600 \mathrm{E}}$ mutations [101-103]. 


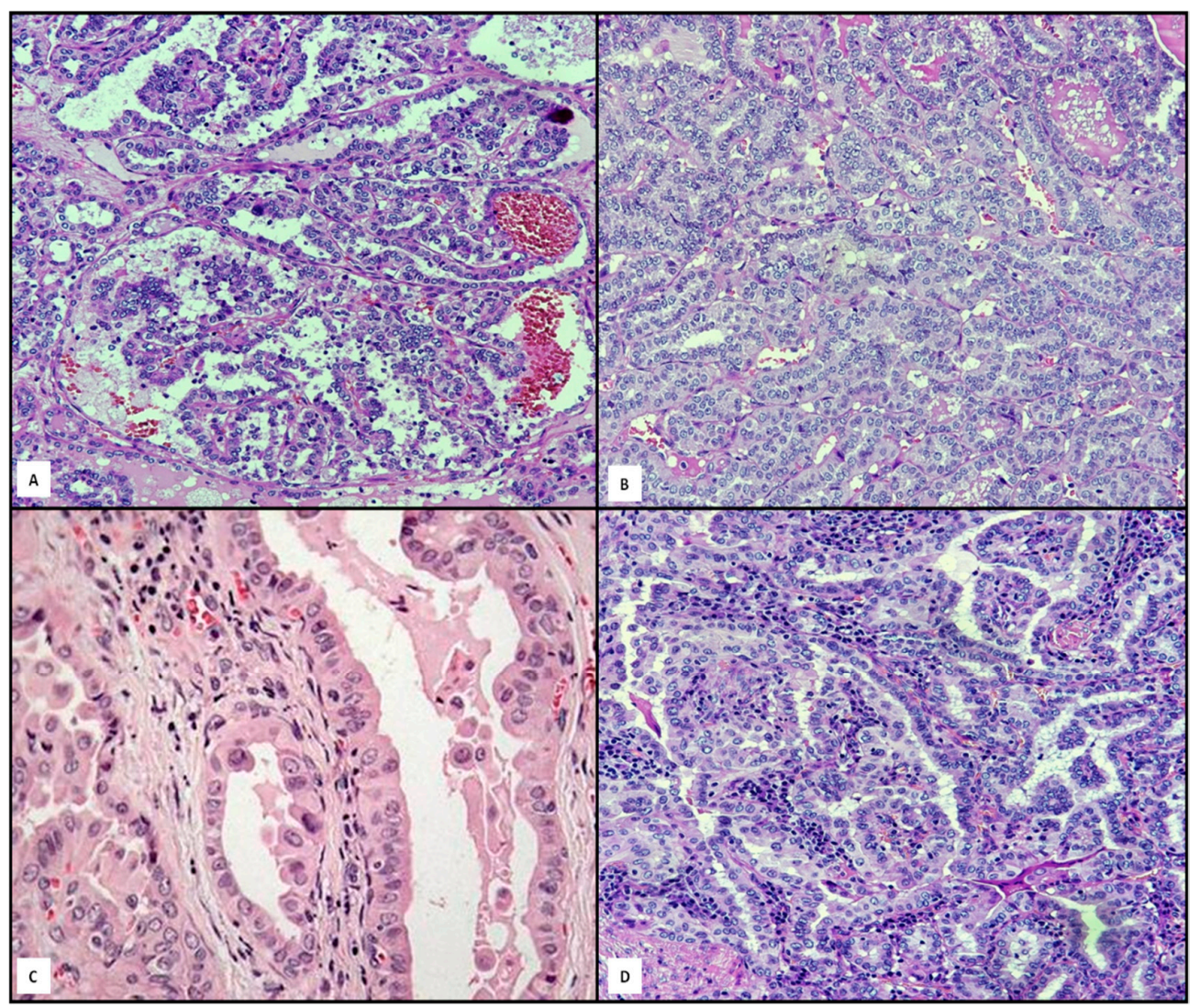

Figure 5. A gallery of some relevant variants of PTC: classical ((A), hematoxylin and eosin, 120 $\times)$; follicular ((B), hematoxylin and eosin, 120×); Whartin-like ((C), hematoxylin and eosin, 120×); micropapillary ((D), hematoxylin and eosin, 160×).

Table 3. Histological and molecular heterogeneity in PTC.

\begin{tabular}{|c|c|c|c|c|c|c|c|c|}
\hline & \multicolumn{8}{|c|}{ Mutations } \\
\hline & EIF1AX & TP53 & RAS & BRAF & TERT & RET & ALK & NOTCH1 \\
\hline Classical PTC & $0-5 \%$ & - & $\mathrm{H} / \mathrm{N} / \mathrm{KRAS} 6 \%$ & $55 \%$ & $5-15 \%$ & $5-25 \%$ & - & - \\
\hline Clear cell/solid variant PTC & - & - & $\mathrm{H} / \mathrm{N} / \mathrm{KRAS} 30 \%$ & $>55 \%$ & - & - & $5 \%$ & - \\
\hline Columnar variant PTC & - & - & - & $33 \%$ & - & - & - & - \\
\hline Tall cell variant PTC & - & - & - & $\begin{array}{c}80- \\
100 \%\end{array}$ & - & - & - & - \\
\hline Hobnail variant PTC & - & $55 \%$ & - & $25 \%$ & - & - & - & $5 \%$ \\
\hline
\end{tabular}

Another common genetic alteration in PTCs is the RET/PTC rearrangement $[105,106]$, which occurs in one third of cases of sporadic PTCs in adults, in half of cases of PTCs in children and young adults, mainly when lymph node metastasis and aggressive clinicopathological features were documented, similarly to NTRK rearranged PTC [107-109]. However, it has been shown that PTCs characterized by fusion oncogene (RET or NTRK) exhibited overlapping clinical behavior [109]. RET/PTC rearrangement has been also frequently observed in subjects exposed to radiation, either accidentally or therapeutically [110]. Moreover, this genetic alteration early occurs in thyroid carcinogenesis, being essentially restricted to PTCs and Hürthle cell tumors [111,112]. Finally, a low rate (1-5\%) of PTCs documented ALK rearrangement in predominant follicular solid infiltrative pattern or in diffuse sclerosing variant, showing sometimes extrathyroidal extension as well as lymph node metastases [113]. 
As said at the beginning of this review, different methods of detection (immunohistochemistry, RT-PCR, RNA analysis after Laser Capture Microdissection) are able to detect RET/PTC rearrangements, the distribution of which may be influenced by intrinsic genetic [111]. Interestingly, Schopper et al. tested a panel of 8 cancer-related genes (BRAF, KRAS, HRAS, NRAS, EGFR, PIK3CA, KIT, and platelet-derived growth factor receptor $\alpha$ polypeptide [PDGFRA]) by using next-generation sequencing (NGS) in a single thyroid tumor presenting as a combination of conventional PTC with 4 variants (follicular, clear cell, columnar and poorly differentiated [112-115]. While conventional PTCs showed only a limited rate of $\mathrm{H} / \mathrm{N} / \mathrm{KRAS}$ mutation $(6 \%)$, the clear cell and the follicular variants harbored KRAS mutations up to 5 times more frequently, viz. 30\% and 20\% respectively [114-116]. Finally, in PTCs the degree of DNA methylation is smaller than in follicular tumors (FA and FTC), and it varies according to BRAF and RAS status [117].

Despite a robust line of research, clinical implications of ITH in PTCs are questioned. Indeed, two studies demonstrated that allelic frequencies of mutated alleles are consistent with a monoclonal origin of PTCs, suggesting ITH in as many as $~ 10 \%$ of tumors $[117,118]$.

\section{Conclusions}

ITH influences tumor progression and response to treatment, as the appearance of resistant clones due to the selection pressure of treatment may worsen the patient's prognosis. Therefore, ITH profiling can be useful to characterize thyroid cancer pathogenesis, together with the analysis of different genetic alterations associated with oncological risk. Nowadays, molecular testing in DTCs suggests a high risk for recurrence of cancer associated with BRAF ${ }^{\mathrm{V} 600 \mathrm{E}}$, RET/PTC 1/3, ALK and NTRK fusions, while the intermediate risk may be related to BRAFK601E, H/K/N RAS and PAX8/PPAR $\gamma$ (Figure 6).

FA/FTC

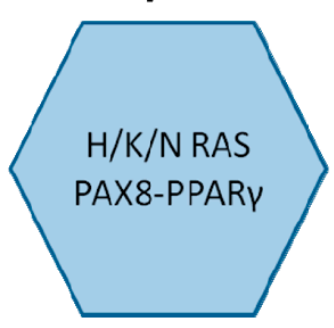

cPTC/TCV-PTC/FVPTC

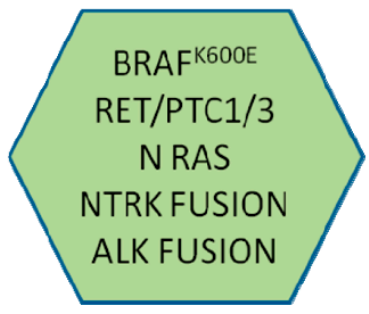

NIFTP/EFVPTC

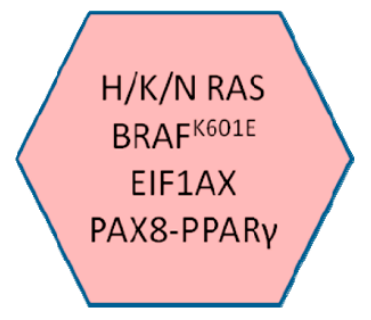

HTC

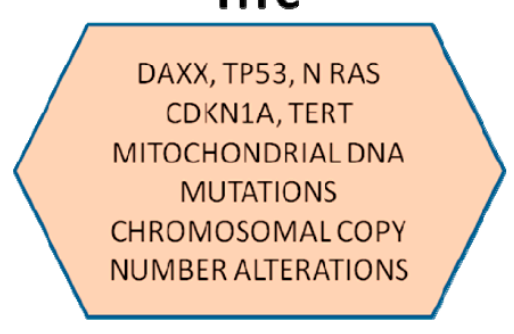

Figure 6. Synopsis showing the main biomolecular mutations in DTCs related to different histotypes.

Consequently, it may be suggested that tumor genotype is associated with peculiar phenotype; therefore, the identification of DTC morphology may be the driver to select different neoplastic portions in which molecular heterogeneity could be revealed. From this point of view, neoplastic sub-populations with different risk of recurrence or metastasis may be advantageously stratified, correctly treated and subjected to a shorter follow-up period. Recently, to measure ITH in cancer, an index has been proposed [119]; in detail, some neoplasms such as uterine carcinosarcoma, colorectal adenocarcinoma and ovarian cancer have been observed to be more heterogeneous than renal clear cell carcinoma and DTC [119]. 
Recent studies based on genetic analysis of thyroid tumors have brought several intriguing therapeutical personalized options for DTCs [120]. This innovative vision in which particularly targeted therapies based on specific diagnostic tests has been defined as "theranostics", in order to provide a transition from conventional to a contemporary personalized medicine [121]. The first theranostic agent has been considered as the radioiodine treatment widely used for the management of DTC. Nevertheless, about $65 \%$ of the patients with advanced thyroid disease may became radioiodine-refractory related to the sodium/iodide symporter (NIS) [120,121]. Therefore, the targeted therapy of DTC should be connected to the genetic and epigenetic alterations and signaling pathways. In detail, PPAR $\gamma$ agonists, HDAC inhibitors, PI3K/AKT inhibitors and MEK/ERK inhibitors, have been recommended for NIS over-expression and have caused improved iodine uptake in thyroid cancers [121]. Moreover, it was shown that Dabrafenib represents the selective inhibitor of mutated forms of $B R A F$ and it can realize the radioiodine uptake in metastatic PTC $B R A F^{V 600 E}$-mutant iodine-refractory patients. Similarly, some molecular markers such as $p 53$, PIK3CA, CTNNB1 and AKT1 may be considered indicators for an aggressive behavior of DTCs [121]. Furthermore, since fine needle aspiration cytology (FNAC) has been considered the commonly utilized morphological test, the molecular profiling may improve the diagnostic accuracy mainly in indeterminate or gray zone, furtherly supporting a personalized treatment for DTCs [122].

A better understanding of the molecular basis of thyroid cancers as well as development of more effective cancer therapies has revolutionized the treatment approach in patients with advanced thyroid cancer. Nevertheless, whether overall survival is improved with the use of these agents is still unclear. In fact, the major limitation in applying targeted therapies is their side-effects profile, as well as in the development of escape and resistance mechanisms by the tumors. Specifically, neoplastic cells may acquire resistance to the treatment by developing an escape mechanism against the targeting drugs. Consequently, most DTCs could develop resistance against targeted drugs by acquiring new mutations that result in over-activation of pathways or by induction of alternate pathways.

Nowadays, the cancer diagnosis should be assessed by a complex of information regarding to clinical, pathological, molecular and protein expression data of a specific neoplastic proliferation and its surrounding microenvironment; such an integrated system has been defined as "tissunomics" [123,124]. In full agreement with this approach, we contend that a systematic integration of morphology and molecular characteristics in DTC should be helpful in patient's management.

Author Contributions: Conceptualization, A.I. and G.T.; writing—original draft preparation, A.I., R.V., C.P., S.B. and G.T.; writing-review and editing, A.I., R.V., C.P., S.B. and G.T.; supervision, S.B. and G.T. All authors have read and agreed to the published version of the manuscript.

Funding: This research received no external funding.

Institutional Review Board Statement: The study was conducted according to the guidelines of the Declaration of Helsinki, and approved by the Institutional Review Board (or Ethics Committee) of Messina University.

Informed Consent Statement: Not applicable.

Data Availability Statement: Not applicable.

Acknowledgments: The authors would like to thank Sandra De Dominici for her skilled technical assistance in reviewing the English style and grammar of the manuscript.

Conflicts of Interest: The authors declare no conflict of interest. 


\begin{tabular}{|c|c|}
\hline AKT1 & $\mathrm{v}$-akt murine thymoma viral oncogene homolog 1 \\
\hline DTC & differentiated thyroid carcinoma \\
\hline DTT & differentiated thyroid tumor \\
\hline EGFR & epidermal growth factor receptor \\
\hline EIF1AX & Factor 1A X-Linked \\
\hline EZH1 & zeste 1 polycomb repressive complex 2 subunit \\
\hline FA & follicular adenoma \\
\hline FTC & follicular thyroid carcinoma \\
\hline GNAS & guanine nucleotide binding protein, alpha stimulating \\
\hline HTT & hyalinizing trabecular tumor \\
\hline ITH & intratumoral heterogeneity \\
\hline MADCAM-1 & Mucosal Vascular Address in Cell Adhesion Molecule 1 \\
\hline NF1 & Neurofibromatosis type 1 \\
\hline NGS & next-generation sequencing \\
\hline NIFTP & noninvasive follicular thyroid neoplasm with papillary-like nuclear features \\
\hline NOTCH1 & Notch homolog-1 \\
\hline PAX-8 & paired box gene 8 \\
\hline PDGFRA & platelet-derived growth factor receptor $\alpha$ polypeptide \\
\hline PI3K & Phosphoinositide 3-kinases \\
\hline PPAR $\gamma$ & peroxisome proliferator-activated receptor- $\gamma$ \\
\hline PTC & papillary thyroid carcinoma \\
\hline PTEN & Phosphatase and tensin homolog \\
\hline RET & REarranged during Transfection \\
\hline $\mathrm{H}, \mathrm{K}, \mathrm{NRA}$ & isoforms of RAS gene family \\
\hline TERT & telomerase reverse transcriptase \\
\hline TSHR & TSH-receptor \\
\hline UMP & uncertain malignant potential tumor \\
\hline WDT-UMP & well-differentiated tumors with uncertain malignant potential \\
\hline
\end{tabular}

\section{References}

1. Bedard, P.L.; Hansen, A.R.; Ratain, M.J.; Siu, L.L. Tumour heterogeneity in the clinic. Nat. Cell Biol. 2013, 501, 355-364. [CrossRef]

2. Fugazzola, L.; Muzza, M.; Pogliaghi, G.; Vitale, M. Intratumoral Genetic Heterogeneity in Papillary Thyroid Cancer: Occurrence and Clinical Significance. Cancers 2020, 12, 383. [CrossRef]

3. Gandolfi, G.; Sancisi, V.; Torricelli, F.; Ragazzi, M.; Frasoldati, A.; Piana, S.; Ciarrocchi, A. Allele Percentage of the BRAF V600E Mutation in Papillary Thyroid Carcinomas and Corresponding Lymph Node Metastases: No Evidence for a Role in Tumor Progression. J. Clin. Endocrinol. Metab. 2013, 98, 934-942. [CrossRef]

4. Schwaederle, M.; Kurzrock, R. Actionability and precision oncology. Oncoscience 2015, 2, 779-780. [CrossRef] [PubMed]

5. Uzilov, A.V.; Ding, W.; Fink, M.Y.; Antipin, Y.; Brohl, A.S.; Davis, C.; Lau, C.Y.; Pandya, C.; Shah, H.; Kasai, Y.; et al. Development and clinical application of an integrative genomic approach to personalized cancer therapy. Genome Med. 2016, 8, 62. [CrossRef] [PubMed]

6. Stanta, G.; Bonin, S. Overview on Clinical Relevance of Intra-Tumor Heterogeneity. Front. Med. 2018, 5, 85. [CrossRef]

7. Stanta, G. Tissue Heterogeneity as a Pre-analytical Source of Variability. Recent Results Cancer Res. 2015, 199, 35-43. [PubMed]

8. Stanta, G.; Jahn, S.W.; Bonin, S.; Hoefler, G. Tumour heterogeneity: Principles and practical consequences. Virchows Arch. Pathol. Anatom. Physiol. Klin. Med. 2016, 469, 371-384. [CrossRef] [PubMed]

9. Masoodi, T.; Siraj, A.K.; Siraj, S.; Azam, S.; Qadri, Z.; Albalawy, W.N.; Parvathareddy, S.K.; Al-Sobhi, S.S.; Al-Dayel, F.; Alkuraya, F.S.; et al. Whole-Exome Sequencing of Matched Primary and Metastatic PapillaryThyroid Cancer. Thyroid 2020, 30, 42-56. [CrossRef]

10. Nabi, K.; Le, A. The Intratumoral Heterogeneity of Cancer Metabolism. Adv. Exp. Med. Biol. 2018, 1063, $131-145$.

11. Tong, Y.; Gao, W.-Q.; Liu, Y. Metabolic heterogeneity in cancer: An overview and therapeutic implications. Biochim. Biophys. Acta Bioenerg. 2020, 1874, 188421. [CrossRef]

12. Marusyk, A.; Janiszewska, M.; Polyak, K. Intratumor Heterogeneity: The Rosetta Stone of Therapy Resistance. Cancer Cell 2020, 37, 471-484. [CrossRef]

13. Hausser, J.; Alon, U. Tumour heterogeneity and the evolutionary trade-offs of cancer. Nat. Rev. Cancer 2020, $20,247-257$. [CrossRef]

14. González-Silva, L.; Quevedo, L.; Varela, I. Tumor Functional Heterogeneity Unraveled by scRNA-seq Technologies. Trends Cancer 2020, 6, 13-19. [CrossRef] 
15. Marusyk, A.; Almendro, V.; Polyak, K. Intra-tumour heterogeneity: A looking glass for cancer? Nat. Rev. Cancer 2012, 12, 323-334. [CrossRef] [PubMed]

16. Xu, C.; Cao, H.; Shi, C.; Feng, J. The Role Of Circulating Tumor DNA In Therapeutic Resistance. Oncotargets Ther. 2019, 12, 9459-9471. [CrossRef] [PubMed]

17. Vessoni, A.T.; Filippi-Chiela, E.C.; Lenz, G.; Batista, L.F.Z. Tumor propagating cells: Drivers of tumor plasticity, heterogeneity, and recurrence. Oncogene 2020, 39, 2055-2068. [CrossRef] [PubMed]

18. Guo, M.; Peng, Y.; Gao, A.; Du, C.; Herman, J.G. Epigenetic heterogeneity in cancer. Biomark. Res. 2019, 7, 1-19. [CrossRef]

19. Palacios, J.; Matías-Guiu, X.; Rodríguez-Peralto, J.L.; de Álava, E.; López, J.I. Clinical challenges and implications of intratumor heterogeneity. Rev. Esp. Patol. 2019, 52, 234-241. [PubMed]

20. Haugen, B.R.; Alexander, E.K.; Bible, K.C.; Doherty, G.M.; Mandel, S.J.; Nikiforov, Y.E.; Pacini, F.; Randolph, G.W.; Sawka, A.M.; Schlumberger, M.; et al. 2015 American Thyroid Association Management Guidelines for Adult Patients with Thyroid Nodules and Differentiated Thyroid Cancer: The American Thyroid Association Guidelines Task Force on Thyroid Nodules and Differentiated Thyroid Cancer. Thyroid 2016, 26, 1-133. [CrossRef] [PubMed]

21. Viola, D.; Valerio, L.; Molinaro, E.; Agate, L.; Bottici, V.; Biagini, A.; Lorusso, L.; Cappagli, V.; Pieruzzi, L.; Giani, C.; et al. Treatment of advanced thyroid cancer with targeted therapies: Ten years of experience. Endocr. Relat. Cancer 2016, 23, R185-R205. [CrossRef] [PubMed]

22. Ieni, A.; Barresi, V.; Cardia, R.; Licata, L.; Di Bari, F.; Benvenga, S.; Tuccari, G. The micropapillary/hobnail variant of papillary thyroid carcinoma: A review of series described in the literature compared to a series from one southern Italy pathology institution. Rev. Endocr. Metab. Disord. 2016, 17, 521-527. [CrossRef] [PubMed]

23. Vita, R.; Ieni, A.; Tuccari, G.; Benvenga, S. The increasing prevalence of chronic lymphocytic thyroiditis in papillary microcarcinoma. Rev. Endocr. Metab. Disord. 2018, 19, 301-309. [CrossRef] [PubMed]

24. Mattiuzzi, C.; Lippi, G. Current Cancer Epidemiology. J. Epidemiol. Glob. Health 2019, 9, 217-222. [CrossRef] [PubMed]

25. Jin, S.; Borkhuu, O.; Bao, W.; Yang, Y.-T. Signaling Pathways in Thyroid Cancer and Their Therapeutic Implications. J. Clin. Med. Res. 2016, 8, 284-296. [CrossRef] [PubMed]

26. Fagin, J.A.; Wells, S.A., Jr. Biologic and Clinical Perspectives on Thyroid Cancer. N. Engl. J. Med. 2016, 375, 1054-1067. [CrossRef] [PubMed]

27. Ieni, A.; Vita, R.; Magliolo, E.; Santarpia, M.; Di Bari, F.; Benvenga, S.; Tuccari, G. One-third of an Archivial Series of Papillary Thyroid Cancer (Years 2007-2015) Has Coexistent Chronic Lymphocytic Thyroiditis, Which Is Associated with a More Favorable Tumor-Node-Metastasis Staging. Front. Endocrinol. 2017, 8, 337. [CrossRef] [PubMed]

28. Haroon, A.; Rasheed, M.R.; Xu, B. Molecular Alterations in Thyroid Carcinoma. Surg. Pathol. Clin. 2019, 12, 921-930. [CrossRef]

29. Tirrò, E.; Martorana, F.; Romano, C.; Vitale, S.R.; Motta, G.; Di Gregorio, S.; Massimino, M.; Pennisi, M.S.; Stella, S.; Puma, A.; et al. Molecular Alterations in Thyroid Cancer: From Bench to Clinical Practice. Genes 2019, 10, 709. [CrossRef]

30. Kakudo, K. How to handle borderline/precursor thyroid tumors in management of patients with thyroid nodules. Gland. Surg. 2018, 7, S8-S18. [CrossRef]

31. Lloyd, R.V.; McNicoll, A. Annual review issue: An overview of 50 years of progress in endocrine pathology. Histopathology 2018, 72, 4-5. [CrossRef] [PubMed]

32. Suster, S. Controversies Regarding the Interpretation of Follicular Thyroid Nodules. Arch. Pathol. Lab. Med. 2019, 143, 1472-1476. [CrossRef] [PubMed]

33. Cameselle-Teijeiro, J.M.; Eloy, C.; Sobrinho-Simões, M. Pitfalls in Challenging Thyroid Tumors: Emphasis on Differential Diagnosis and Ancillary Biomarkers. Endocr. Pathol. 2020, 31, 197-217. [CrossRef] [PubMed]

34. Baloch, Z.; Livolsi, V.A. Fifty years of thyroid pathology: Concepts and developments. Hum. Pathol. 2020, 95, 46-54. [CrossRef] [PubMed]

35. Borda, A.; Zahan, A.-E.; Piciu, D.; Barbuș, E.; Berger, N.; Nechifor-Boilă, A. A 15 year institutional experience of well-differentiated follicular cell-derived thyroid carcinomas; impact of the new 2017 TNM and WHO Classifications of Tumors of Endocrine Organs on the epidemiological trends and pathological characteristics. Endocrinology 2020, 67, 630-642. [CrossRef] [PubMed]

36. Zhu, Y.; Li, Y.; Jung, C.K.; Song, D.E.; Hang, J.-F.; Liu, Z.; Jain, D.; Lai, C.-R.; Hirokawa, M.; Kakudo, K.; et al. Histopathologic Assessment of Capsular Invasion in Follicular Thyroid Neoplasms-an Observer Variation Study. Endoc. Pathol. 2020, $31,132$. [CrossRef]

37. Cracolici, V.; Ritterhouse, L.L.; Segal, J.P.; Puranik, R.; Wanjari, P.; Kadri, S.; Parilla, M.; Cipriani, N.A. Follicular Thyroid Neoplasms: Comparison of Clinicopathologic and Molecular Features of Atypical Adenomas and Follicular Thyroid Carcinomas. Am. J. Surg. Pathol. 2020, 44, 881-892. [CrossRef]

38. Chu, Y.-H.; Sadow, P.M. Noninvasive follicular thyroid neoplasm with papillary-like nuclear features (NIFTP): Diagnostic updates and molecular advances. Semin. Diagn. Pathol. 2020, 37, 213-218. [CrossRef]

39. Livolsi, V.A.; Baloch, Z. Noninvasive Follicular Tumor With Papillary-like Nuclear Features: A Practice Changer in Thyroid Pathology. Arch. Pathol. Lab. Med. 2020, 30, 1-5. [CrossRef]

40. Katsakhyan, L.; Song, S.; Lepe, M.; Shojaei, H.; Montone, K.T.; Livolsi, V.A.; Baloch, Z.W. Practice Paradigms Before and After Introduction of the Diagnosis-Noninvasive Follicular Thyroid Neoplasm with Papillary-Like Nuclear Features (NIFTP): An Institutional Experience. Endocr. Pathol. 2020, 31, 174-181. [CrossRef] [PubMed] 
41. Xu, B.; Ghossein, R.A. Noninvasive Follicular Thyroid Neoplasm with Papillary-Like Nuclear Features (NIFTP): An Update. Head Neck Pathol. 2020, 14, 303-310. [CrossRef]

42. Nikiforov, Y.E.; Seethala, R.R.; Tallini, G.; Baloch, Z.W.; Basolo, F. Nomenclature revision for encapsulated follicular variant of papillary thyroid carcinoma: A paradigm shift to reduce overtreatment of indolent tumors. JAMA Oncol. 2016, 2, 1023-1029. [CrossRef]

43. Haugen, B.R.; Sawka, A.M.; Alexander, E.K.; Bible, K.C.; Caturegli, P.; Doherty, G.M.; Mandel, S.J.; Morris, J.C.; Nassar, A.; Pacini, F.; et al. American Thyroid Association Guidelines on the Management of Thyroid Nodules and Differentiated Thyroid Cancer Task Force Review and Recommendation on the Proposed Renaming of Encapsulated Follicular Variant Papillary Thyroid Carcinoma Without Invasion to Noninvasive Follicular Thyroid Neoplasm with Papillary-Like Nuclear Features. Thyroid 2017, 27, 481-483.

44. Rossi, E.D.; Papotti, M.; Faquin, W.; LaRocca, L.M.; Pantanowitz, L. The Diagnosis of Hyalinizing Trabecular Tumor: A Difficult and Controversial Thyroid Entity. Head Neck Pathol. 2020, 14, 778-784. [CrossRef] [PubMed]

45. Jones, D.J.; Kieliszak, C.R.; Patel, S.S.; Selinsky, C.R. Hyalinizing trabecular tumor of the thyroid gland and its significant diagnostic issue. Thyroid Res. 2017, 10, 7. [CrossRef]

46. Saglietti, C.; Piana, S.; La Rosa, S.; Bongiovanni, M. Hyalinizing trabecular tumour of the thyroid: Fine-needle aspiration cytological diagnosis and correlation with histology. J. Clin. Pathol. 2017, 70, 641-647. [CrossRef] [PubMed]

47. Jung, C.K.; Kim, Y.; Jeon, S.; Jo, K.; Lee, S.; Bae, J.S. Clinical utility of EZH1 mutations in the diagnosis of follicular-patterned thyroid tumors. Hum. Pathol. 2018, 81, 9-17. [CrossRef] [PubMed]

48. Algeciras-Schimnich, A.; Milosevic, D.; McIver, B.; Flynn, H.; Reddi, H.V.; Eberhardt, N.L.; Grebe, S.K. Evaluation of the PAX8/PPARG Translocation in Follicular Thyroid Cancer with a 4-Color Reverse-Transcription PCR Assay and Automated High-Resolution Fragment Analysis. Clin. Chem. 2010, 56, 391-398. [CrossRef]

49. Basili, T.; Dopeso, H.; Kim, S.H.; Ferrando, L.; Pareja, F.; Paula, A.D.C.; Da Silva, E.M.; Stylianou, A.; Maroldi, A.; Marchiò, C.; et al. Oncogenic properties and signaling basis of the PAX8-GLIS3 fusion gene. Int. J. Cancer 2020, 147, 2253-2264. [CrossRef]

50. Acquaviva, G.; Visani, M.; Repaci, A.; Rhoden, K.J.; De Biase, D.; Pession, A.; Giovanni, T. Molecular pathology of thyroid tumours of follicular cells: A review of genetic alterations and their clinicopathological relevance. Histopathology 2017, 72, 6-31. [CrossRef]

51. Duan, H.; Liu, X.; Ren, X.; Zhang, H.; Wu, H.; Liang, Z. Mutation profiles of follicular thyroid tumors by targeted sequencing. Diagn. Pathol. 2019, 14, 1-10. [CrossRef]

52. Boaventura, P.; Batista, R.; Pestana, A.; Reis, M.; Mendes, A.; Eloy, C.; Sobrinho-Simões, M.; Soares, P. TERT promoter mutations: A genetic signature of benign and malignant thyroid tumours occurring in the context of tinea capitis irradiation. Eur. J. Endocrinol. 2017, 176, 49-55. [CrossRef]

53. Calebiro, D.; Grassi, E.S.; Eszlinger, M.; Ronchi, C.L.; Godbole, A.; Bathon, K.; Guizzardi, F.; De Filippis, T.; Krohn, K.; Jaeschke, H. Recurrent EZH1 mutations are a second hit in autonomous thyroid adenomas. J. Clin. Investig. 2016, 126, 3383-3388. [CrossRef]

54. Nikiforov, Y.E.; Nikiforova, M.N. Molecular genetics and diagnosis of thyroid cancer. Nat. Rev. Endocrinol. 2011, 7, 569-580. [CrossRef]

55. Lorusso, L.; Cappagli, V.; Valerio, L.; Giani, C.; Viola, D.; Puleo, L.; Gambale, C.; Minaldi, E.; Campopiano, M.C.; Matrone, A.; et al. Thyroid Cancers: From Surgery to Current and Future Systemic Therapies through Their Molecular Identities. Int. J. Mol. Sci. 2021, 22, 3117. [CrossRef]

56. Führer, D.; Musholt, T.; Schmid, K.W. Molecular Pathogenesis of Thyroid Nodules: Relevance for Clinical Care. Laryngorhinootologie 2017, 96, 590-596. [PubMed]

57. Nikiforova, M.N.; Nikitski, A.V.; Panebianco, F.; Kaya, C.; Yip, L.; Williams, M.D.; Chiosea, S.I.; Seethala, R.R.; Roy, S.; Condello, V.; et al. GLIS Rearrangement is a Genomic Hallmark of Hyalinizing Trabecular Tumor of the Thyroid Gland. Thyroid 2019, 29, 161-173. [CrossRef] [PubMed]

58. Sobrinho-Simões, M.; Preto, A.; Rocha, A.S.; Castro, P.; Máximo, V.; Fonseca, E.; Soares, P. Molecular pathology of welldifferentiated thyroid carcinomas. Virchows Arch. 2005, 447, 787-793. [CrossRef]

59. Asa, S.L. The Current Histologic Classification of Thyroid Cancer. Endocrinol. Metab. Clin. N. Am. 2019, 48, 1-22. [CrossRef]

60. Xu, B.; Ghossein, R. Evolution of the histologic classification of thyroid neoplasms and its impact on clinical management. Eur. J. Surg. Oncol. 2018, 44, 338-347. [CrossRef] [PubMed]

61. Xu, B.; A Ghossein, R. Crucial parameters in thyroid carcinoma reporting-Challenges, controversies and clinical implications. Histopathology 2018, 72, 32-39. [CrossRef]

62. Asa, S.L. The evolution of differentiated thyroid cancer. Pathology 2017, 49, 229-237. [CrossRef]

63. Kakudo, K.; Bai, Y.; Liu, Z.; Li, Y.; Ito, Y.; Ozaki, T. Classification of thyroid follicular cell tumors: With special reference to borderline lesions [Review]. Endocr. J. 2012, 59, 1-12. [CrossRef]

64. Angell, T.E. RAS-positive thyroid nodules. Curr. Opin. Endocrinol. Diabetes Obes. 2017, 24, 372-376. [CrossRef]

65. Nabhan, F.; Porter, K.; Lupo, M.A.; Randolph, G.W.; Patel, K.N.; Kloos, R.T. Heterogeneity in Positive Predictive Value of RAS Mutations in Cytologically Indeterminate Thyroid Nodules. Thyroid 2018, 28, 729-738. [CrossRef]

66. Yoo, S.K.; Lee, S.; Kim, S.J.; Jee, H.G.; Kim, B.A.; Cho, H.; Song, Y.S.; Cho, S.W.; Won, J.K.; Shin, J.Y.; et al. Comprehensive Analysis of the Transcriptional and Mutational Landscape of Follicular and Papillary Thyroid Cancers. PLoS Genet. 2016, 12, e1006239. [CrossRef] [PubMed] 
67. Chmielik, E.; Rusinek, D.; Oczko-Wojciechowska, M.; Jarzab, M.; Krajewska, J.; Czarniecka, A.; Jarzab, B. Heterogeneity of Thyroid Cancer. Pathobiology 2018, 85, 117-129. [CrossRef] [PubMed]

68. The AACR Project GENIE Consortium. AACR Project GENIE: Powering precision medicine through an international consortium. Cancer Discov. 2017, 7, 818-831. [CrossRef] [PubMed]

69. Xu, B.; Ghossein, R. Poorly differentiated thyroid carcinoma. Semin. Diagn. Pathol. 2020, 37, 243-247. [CrossRef] [PubMed]

70. Song, Y.S.; Park, Y.J. Genomic Characterization of Differentiated Thyroid Carcinoma. Endocrinol. Metab. 2019, 34, 1-10. [CrossRef] [PubMed]

71. Yoo, S.-K.; Song, Y.S.; Park, Y.J.; Seo, J.-S. Recent Improvements in Genomic and Transcriptomic Understanding of Anaplastic and Poorly Differentiated Thyroid Cancers. Endocrinol. Metab. 2020, 35, 44-54. [CrossRef]

72. Volante, M.; Rapa, I.; Gandhi, M.; Bussolati, G.; Giachino, D.; Papotti, M.; Nikiforov, Y.E. RAS Mutations Are the Predominant Molecular Alteration in Poorly Differentiated Thyroid Carcinomas and Bear Prognostic Impact. J. Clin. Endocrinol. Metab. 2009, 94, 4735-4741. [CrossRef] [PubMed]

73. Jalaly, J.B.; Baloch, Z.W. Hürthle-cell neoplasms of the thyroid: An algorithmic approach to pathologic diagnosis in light of molecular advances. Semin. Diagn. Pathol. 2020, 37, 234-242. [CrossRef] [PubMed]

74. Sugino, K.; Kameyama, K.; Ito, K.; Nagahama, M.; Kitagawa, W.; Shibuya, H.; Ohkuwa, K.; Uruno, T.; Akaishi, J.; Suzuki, A.; et al. Does Hürthle Cell Carcinoma of the Thyroid Have a Poorer Prognosis than Ordinary Follicular Thyroid Carcinoma? Ann. Surg. Oncol. 2013, 20, 2944-2950. [CrossRef]

75. Kim, S.K.; Yun, G.Y.; Kim, K.H.; Park, S.K.; Choi, H.Y.; Ha, S.K.; Park, H.C. Severe Hyponatremia Following Radioactive Iodine Therapy in Patients with Differentiated Thyroid Cancer. Thyroid 2014, 24, 773-777. [CrossRef]

76. Zirilli, G.; Valenzise, M.; Dionigi, G.; Tuccari, G.; Romeo, C.; Campennì, A.; Corrias, A.; Tuli, G.; Ieni, A.; Pajno, G.B.; et al. Hurthle cell carcinoma in childhood: A retrospective analysis of five cases and review of pediatric literature. Pediatr Blood Cancer. 2020, 67, e28300. [CrossRef]

77. Ganly, I.; Makarov, V.; Deraje, S.; Dong, Y.; Reznik, E.; Seshan, V.; Nanjangud, G.; Eng, S.; Bose, P.; Kuo, F.; et al. Integrated Genomic Analysis of Hürthle Cell Cancer Reveals Oncogenic Drivers, Recurrent Mitochondrial Mutations, and Unique Chromosomal Landscapes. Cancer Cell 2018, 34, 256-270. [CrossRef]

78. Gopal, R.K.; Kübler, K.; Calvo, S.E.; Polak, P.; Livitz, D.; Rosebrock, D.; Sadow, P.M.; Campbell, B.; Donovan, S.E.; Amin, S.; et al. Widespread Chromosomal Losses and Mitochondrial DNA Alterations as Genetic Drivers in Hürthle Cell Carcinoma. Cancer Cell 2018, 34, 242-255. [CrossRef] [PubMed]

79. Kumari, S.; Adewale, R.; Klubo-Gwiezdzinska, J. The Molecular Landscape of Hürthle Cell Thyroid Cancer Is Associated with Altered Mitochondrial Function-A Comprehensive Review. Cells 2020, 9, 1570. [CrossRef]

80. Olson, E.; Wintheiser, G.; Wolfe, K.M.; Droessler, J.; Silberstein, P.T. Epidemiology of Thyroid Cancer: A Review of the National Cancer Database, 2000-2013. Cureus 2019, 11, e4127. [CrossRef] [PubMed]

81. Hernandez-Prera, J.C. The evolving concept of aggressive histological variants of differentiated thyroid cancer. Semin. Diagn. Pathol. 2020, 37, 228-233. [CrossRef] [PubMed]

82. Póvoa, A.A.; Teixeira, E.; Bella-Cueto, M.R.; Melo, M.; Oliveira, M.J.; Sobrinho-Simões, M.; Maciel, J.; Soares, P. Clinicopathological Features as Prognostic Predictors of Poor Outcome in Papillary Thyroid Carcinoma. Cancers 2020, 12, 3186. [CrossRef] [PubMed]

83. Nath, M.C.; Erickson, L.A. Aggressive Variants of Papillary Thyroid Carcinoma: Hobnail, Tall Cell, Columnar, and Solid. Adv. Anat. Pathol. 2018, 25, 172-179. [CrossRef]

84. Hu, J.; Yuan, I.J.; Mirshahidi, S.; Simental, A.; Lee, S.C.; Yuan, X. Thyroid Carcinoma: Phenotypic Features, Underlying Biology and Potential Relevance for Targeting Therapy. Int. J. Mol. Sci. 2021, 22, 1950.

85. Nagayama, Y.; Mishima, H. Heterogenous nature of gene expression patterns in BRAF-like papillarythyroid carcinomas with BRAF(V600E). Endocrine 2019, 66, 607-613. [CrossRef]

86. Colombo, C.; Muzza, M.; Proverbio, M.C.; Tosi, D.; Soranna, D.; Pesenti, C.; Rossi, S.; Cirello, V.; De Leo, S.; Fusco, N.; et al. Impact of Mutation Density and Heterogeneity on Papillary Thyroid Cancer Clinical Features and Remission Probability. Thyroid 2019, 29, 237-251. [CrossRef] [PubMed]

87. Ieni, A.; Vita, R.; Cardia, R.; Giuffrè, G.; Benvenga, S.; Tuccari, G. BRAF Status in Papillary Microcarcinomas of the Thyroid Gland: A Brief Review. Curr. Mol. Med. 2019, 19, 665-672. [CrossRef]

88. Rangel-Pozzo, A.; Sisdelli, L.; Cordioli, M.I.V.; Vaisman, F.; Caria, P.; Mai, S.; Cerutti, J.M. Genetic Landscape of Papillary Thyroid Carcinoma and Nuclear Architecture: An Overview Comparing Pediatric and Adult Populations. Cancers 2020, $12,3146$. [CrossRef]

89. Li, D.-D.; Zhang, Y.-F.; Xu, H.-X.; Zhang, X.-P. The role of BRAF in the pathogenesis of thyroid carcinoma. Front. Biosci. 2015, 20, 1068-1078.

90. Zhao, L.; Wang, L.; Jia, X.; Hu, X.; Pang, P.; Zhao, S.; Wang, Y.; Wang, J.; Zhang, Y.; Lyu, Z. The Coexistence of Genetic Mutations in Thyroid Carcinoma Predicts Histopathological Factors Associated With a Poor Prognosis: A Systematic Review and Network Meta-Analysis. Front. Oncol. 2020, 10, 10-540238. [CrossRef]

91. Kim, K.J.; Kim, S.G.; Tan, J.; Shen, X.; Viola, D.; Elisei, R.; Puxeddu, E.; Fugazzola, L.; Colombo, C.; Jarzab, B.; et al. BRAF V600E status may facilitate decision-making on active surveillance of low-risk papillary thyroid microcarcinoma. Eur. J. Cancer 2020, 124, 161-169. [CrossRef] 
92. Wong, K.S.; Higgins, S.E.; Marqusee, E.; Nehs, M.A.; Angell, T.; Barletta, J.A. Tall Cell Variant of Papillary Thyroid Carcinoma: Impact of Change in WHO Definition and Molecular Analysis. Endocr. Pathol. 2018, 30, 43-48. [CrossRef]

93. Vuong, H.G.; Long, N.P.; Anh, N.H.; Nghi, T.D.; Hieu, M.V.; Hung, L.P.; Nakazawa, T.; Katoh, R.; Kondo, T. Papillary thyroid carcinoma with tall cell features is as aggressive as tall cellvariant: A meta-analysis. Endocr. Connect. 2018, 7, R286-R293. [CrossRef]

94. Donaldson, L.B.; Yan, F.; Morgan, P.F.; Kaczmar, J.M.; Fernandes, J.K.; Nguyen, S.A.; Jester, R.L.; Day, T.A. Hobnail variant of papillary thyroid carcinoma: A systematic review and meta-analysis. Endocrine 2020,1-13. [CrossRef]

95. Watutantrige-Fernando, S.; Vianello, F.; Barollo, S.; Bertazza, L.; Galuppini, F.; Cavedon, E.; Censi, S.; Benna, C.; Ide, E.C.; Parisi, A.; et al. The Hobnail Variant of Papillary Thyroid Carcinoma: Clinical/Molecular Characteristics of a Large Monocentric Series and Comparison with Conventional Histotypes. Thyroid 2018, 28, 96-103. [CrossRef]

96. Ambrosi, F.; Righi, A.; Ricci, C.; Erickson, L.A.; Lloyd, R.V.; Asioli, S. Hobnail Variant of Papillary Thyroid Carcinoma: A Literature Review. Endocr. Pathol. 2017, 28, 293-301. [CrossRef] [PubMed]

97. Walts, A.E.; Pao, A.; Sacks, W.; Bose, S. BRAF genetic heterogeneity in papillary thyroid carcinoma and its metastasis. Hum. Pathol. 2014, 45, 935-941. [CrossRef] [PubMed]

98. Le Pennec, S.; Konopka, T.; Gacquer, D.; Fimereli, D.; Tarabichi, M.; Tomás, G.; Savagner, F.; Decaussin-Petrucci, M.; Trésallet, C.; Andry, G.; et al. Intratumor heterogeneity and clonal evolution in an aggressive papillary thyroid cancer and matched metastases. Endocr. Relat. Cancer 2015, 22, 205-216. [CrossRef]

99. Gawin, M.; Kurczyk, A.; Stobiecka, E.; Frątczak, K.; Polańska, J.; Pietrowska, M.; Widłak, P. Molecular Heterogeneity of Papillary Thyroid Cancer: Comparison of Primary Tumors and Synchronous Metastases in Regional Lymph Nodes by Mass Spectrometry Imaging. Endocr. Pathol. 2019, 30, 250-261. [CrossRef]

100. Oler, G.; Ebina, K.N.; Michaluart, P.; Kimura, E.T.; Cerutti, J. Investigation of BRAF mutation in a series of papillary thyroid carcinoma and matched-lymph node metastasis reveals a new mutation in metastasis. Clin. Endocrinol. 2005, 62, 509-511. [CrossRef] [PubMed]

101. Vasko, V.; Hu, S.; Wu, G.; Xing, J.C.; Larin, A.; Savchenko, V.; Trink, B.; Xing, M.; Larin, O. High Prevalence and Possible de Novo Formation of BRAF Mutation in Metastasized Papillary Thyroid Cancer in Lymph Nodes. J. Clin. Endocrinol. Metab. 2005, 90, 5265-5269. [CrossRef]

102. Chen, P.; Pan, L.; Huang, W.; Feng, H.; Ouyang, W.; Wu, J.; Wang, J.; Deng, Y.; Luo, J.; Chen, Y. BRAF V600E and lymph node metastases in papillary thyroid cancer. Endocr. Connect. 2020, 9, 999-1008. [CrossRef] [PubMed]

103. Guerra, A.; Fugazzola, L.; Marotta, V.; Cirillo, M.; Rossi, S.; Cirello, V.; Forno, I.; Moccia, T.; Budillon, A.; Vitale, M. A High Percentage of BRAFV600E Alleles in Papillary Thyroid Carcinoma Predicts a Poorer Outcome. J. Clin. Endocrinol. Metab. 2012, 97, 2333-2340. [CrossRef]

104. Guerra, A.; Sapio, M.R.; Marotta, V.; Campanile, E.; Rossi, S.; Forno, I.; Fugazzola, L.; Budillon, A.; Moccia, T.; Fenzi, G.; et al. The primary occurrence of $\mathrm{BRAF}(\mathrm{V} 600 \mathrm{E})$ is a rare clonal event in papillary thyroid carcinoma. J. Clin. Endocrinol. Metab. 2012, 97, 517-524. [CrossRef]

105. Khan, M.S.; Qadri, Q.; Makhdoomi, M.J.; A Wani, M.; A Malik, A.; Niyaz, M.; Masoodi, S.R.; I Andrabi, K.; Ahmad, R.; Mudassar S. RET/PTC Gene Rearrangements in Thyroid Carcinogenesis: Assessment and Clinico-Pathological Correlations. Pathol. Oncol. Res. 2020, 26, 507-513. [CrossRef] [PubMed]

106. Staubitz, J.I.; Schad, A.; Springer, E.; Rajalingam, K.; Lang, H.; Roth, W.; Hartmann, N.; Musholt, T.J. Novel rearrangements involving the RET gene in papillary thyroid carcinoma. Cancer Genet. 2019, 230, 13-20. [CrossRef]

107. Yakushina, V.D.; Lerner, L.V.; Lavrov, A.V. Gene Fusions in Thyroid Cancer. Thyroid 2018, 158-167. [CrossRef] [PubMed]

108. Cordioli, M.I.; Moraes, L.; Bastos, A.U.; Besson, P.; Alves, M.T.; Delcelo, R.; Monte, O.; Longui, C.; Cury, A.N.; Cerutti, J.M. Fusion Oncogenes Are the Main Genetic Events Found in Sporadic PapillaryThyroid Carcinomas from Children. Thyroid 2017, 27, 182-188. [CrossRef]

109. Prasad, M.L.; Vyas, M.; Horne, M.J.; Virk, R.K.; Morotti, R.; Liu, Z.; Tallini, G.; Nikiforova, M.N.; Christison-Lagay, E.R.; Udelsman, R.; et al. NTRK fusion oncogenes in pediatric papillary thyroid carcinoma in northeast United States. Cancer 2016, 122, 1097-1107. [CrossRef]

110. Iglesias, M.L.; Schmidt, A.; Al Ghuzlan, A.; Lacroix, L.; De Vathaire, F.; Chevillard, S.; Schlumberger, M. Radiation exposure and thyroid cancer: A review. Arch. Endocrinol. Metab. 2017, 61, 180-187. [CrossRef]

111. Ciampi, R.; Nikiforov, Y.E. Alterations of the BRAF Gene in Thyroid Tumors. Endocr. Pathol. 2005, 16, 163-172. [CrossRef]

112. Nozaki, Y.; Yamamoto, H.; Iwasaki, T.; Sato, M.; Jiromaru, R.; Hongo, T.; Yasumatsu, R.; Oda, Y. Clinicopathological features and immunohistochemical utility of NTRK-, ALK-, and ROS1-rearranged papillary thyroid carcinomas and anaplastic thyroid carcinomas. Hum. Pathol. 2020, 106, 82-92. [CrossRef]

113. Chou, A.; Fraser, S.; Toon, C.W.; Clarkson, A.; Sioson, L.; Farzin, M.; Cussigh, C.; Aniss, A.; O’Neill, C.; Watson, N.; et al. A Detailed Clinicopathologic Study of ALK-translocated Papillary Thyroid Carcinoma. Am. J. Surg. Pathol. 2015, 39, 652-659. [CrossRef]

114. Park, J.Y.; Kim, W.Y.; Hwang, T.S.; Lee, S.S.; Kim, H.; Han, H.S.; Lim, S.D.; Kim, W.S.; Yoo, Y.B.; Park, K.S. BRAF and RAS Mutations in Follicular Variants of Papillary Thyroid Carcinoma. Endocr. Pathol. 2013, 24, 69-76. [CrossRef] [PubMed]

115. Schopper, H.K.; Stence, A.; Ma, D.; A Pagedar, N.; A Robinson, R. Single thyroid tumour showing multiple differentiated morphological patterns and intramorphological molecular genetic heterogeneity. J. Clin. Pathol. 2016, 70, 116-119. [CrossRef] 
116. Cipriani, N.A.; Agarwal, S.; Dias-Santagata, D.; Faquin, W.C.; Sadow, P.M. Clear Cell Change in Thyroid Carcinoma: A Clinicopathologic and Molecular Study with Identification of Variable Genetic Anomalies. Thyroid 2017, 27, 819-824. [CrossRef] [PubMed]

117. Mancikova, V.; Buj, R.; Castelblanco, E.; Inglada-Pérez, L.; Diez, A.; De Cubas, A.A.; Curras-Freixes, M.; Maravall, F.X.; Mauricio, D.; Matias-Guiu, X.; et al. DNA methylation profiling of well-differentiated thyroid cancer uncovers markers of recurrence free survival. Int. J. Cancer 2013, 135, 598-610. [CrossRef] [PubMed]

118. Carter, S.L.; Cibulskis, K.; Helman, E.; McKenna, A.; Shen, H.; Zack, T.; Laird, P.W.; Onofrio, R.C.; Winckler, W.; Weir, B.A.; et al. Absolute quantification of somatic DNA alterations in human cancer. Nat. Biotechnol. 2012, 30, 413-421. [CrossRef]

119. Oh, B.Y.; Shin, H.-T.; Yun, J.W.; Kim, K.-T.; Kim, J.; Bae, J.S.; Cho, Y.B.; Lee, W.Y.; Yun, S.H.; Park, Y.A.; et al. Intratumor heterogeneity inferred from targeted deep sequencing as a prognostic indicator. Sci. Rep. 2019, 9, 4542. [CrossRef] [PubMed]

120. Khatami, F.; Larijani, B.; Nikfar, S.; Hasanzad, M.; Fendereski, K.; Tavangar, S.M. Personalized treatment options for thyroid cancer: Current perspectives. Pharm. Pers. Med. 2019, 12, 235-245. [CrossRef] [PubMed]

121. Campennì, A.; Barbaro, D.; Guzzo, M.; Capoccetti, F.; Giovanella, L. Personalized management of differentiated thyroid cancer in real life-practical guidance from a multidisciplinary panel of experts. Endocrines 2020, 70, 280-291. [CrossRef] [PubMed]

122. Nishino, M. Sustainable cytopathology in the precision medicine era: Exploring new sources for molecular testing in thyroid cytology specimens. Cancer Cytopathol. 2019, 127, 143-145. [CrossRef]

123. Ramón Y Cajal, S.; Hümmer, S.; Peg, V.; Guiu, X.M.; De Torres, I.; Castellvi, J.; Martinez-Saez, E.; Hernandez-Losa, J. Integrating clinical, molecular, proteomic and histopathological data within the tissue context: Tissunomics. Histopathology 2019, 75, 4-19. [CrossRef] [PubMed]

124. Ramón Y Cajal, S.; Sesé, M.; Capdevila, C.; Aasen, T.; De Mattos-Arruda, L.; Diaz-Cano, S.J.; Hernández-Losa, J.; Castellví, J. Clinical implications of intratumor heterogeneity: Challenges and opportunities. J. Mol. Med. 2020, 98, 161-177. [CrossRef] [PubMed] 